\title{
SPANXN2 Gene
}

National Cancer Institute

\section{Source}

National Cancer Institute. SPANXN2 Gene. NCI Thesaurus. Code C92988.

This gene may play a role in spermatid development. 